\title{
Hypolipidemic Activity of Olive Oil (Olea europaea) against High Fat Diet-Induced Nonalcoholic Fatty Liver Disease (NAFLD) in Mice
}

\author{
Farooq Ahmed Wani ${ }^{*}$, Abdalla Z. Albahrawy ${ }^{2}$, Shaik Rahiman ${ }^{3}$ \\ ${ }^{1}$ Department of Pathology, College of Medicine, Aljouf University, Aljouf, Saudi Arabia \\ ${ }^{2}$ Department of Biology, College of Science, Aljouf University, Aljouf, Saudi Arabia \\ ${ }^{3}$ Department of Biochemistry, College of Medicine, Aljouf University, Aljouf, Saudi Arabia \\ Email: ${ }^{*}$ fawani@ju.edu.sa
}

Received 20 May 2015; accepted 13 June 2015; published 16 June 2015

Copyright (c) 2015 by authors and Scientific Research Publishing Inc.

This work is licensed under the Creative Commons Attribution International License (CC BY). http://creativecommons.org/licenses/by/4.0/

c) (i) Open Access

\begin{abstract}
Aim: The aim of the present study is to access the effect of olive oil supplementation against high fat diet induced fatty liver disease in mice. Methods: Mice were divided into five groups: Group I (normal diet), Group II (high fat diet), Group III (olive oil), Group IV and V (High Fat Diet along with olive oil). All mice were fed for 16 weeks with weight measurements every 2 weeks and then sacrificed. Biochemical analysis of blood samples was done and mice livers were histologically examined. Results: Group II mice showed significant increase in body weight as compared with Group I $(p<0.05)$. Group IV and V mice were significantly $(p<0.05)$ reduced in body weight as compared with Group II. Olive oil groups had significantly decreased triglyceride and low density lipoprotein levels as compared with Group II whereas high density lipoprotein levels were significantly increased $(p<0.05)$. The liver enzymes were significantly increased in Group II as compared with other groups $(p<0.05)$. Liver histopathology revealed drastically increased lipid droplets in Group II mice as compared with Group IV \& V. Conclusion: Olive oil causes weight reduction, decreases the serum triglycerides, normalizes the liver enzymes and significantly reduces the accumulation of fat in liver. Therefore, olive oil may represent a potential therapeutic alternative for NAFLD and other fatty diseases.
\end{abstract}

\section{Keywords}

Nonalcoholic Fatty Liver Disease, Olive Oil, High Fat Diet, Liver

\footnotetext{
${ }^{*}$ Corresponding author.
}

How to cite this paper: Wani, F.A., Albahrawy, A.Z. and Rahiman, S. (2015) Hypolipidemic Activity of Olive Oil (Olea europaea) against High Fat Diet-Induced Nonalcoholic Fatty Liver Disease (NAFLD) in Mice. Open Journal of Pathology, 5, 73-83. http://dx.doi.org/10.4236/ojpathology.2015.53011 


\section{Introduction}

Liver is the most complex and largest internal organ in the human body. It plays a core role in the maintenance of systemic lipid homeostasis through its multiple and diverse functions [1]. It regulates the internal environment through its vital functions such as metabolism, storage and secretion [2]. Among the common metabolic disorders in the world, non-alcoholic fatty liver disease (NAFLD) is considered as the most prominent one and it accounts for $70 \%-90 \%$ of cases occurring as a complication of type 2 diabetes, obesity and other metabolic related disorders [3]. NAFLD is characterized by triacylglycerol accumulation inside liver cells from periphery adipose depots due to several risk factors such as current urbanization and lifestyle changes (like high-fat rich diet), diabetes and high genetic tendency [4]. In NAFLD, fatty acid mobilization is increased from peripheral adipose tissue and liver decreases the utilization of fatty acids and increases its synthesis in the hepatocytes. Also there is decreased fat secretion from the liver and increased esterification of fat resulting in accumulation of net fat in the liver cells [5] [6]. The progression of this condition leads to more severe non-alcoholic steatohepatitis (NASH) of liver, cirrhosis of liver and liver fibrosis [3]. Furthermore, insulin resistance coupled with oxidative stress results in NAFLD [7] [8] in the absence of significant consumption of alcohol [4]. Initially NAFLD begins as simple liver steatosis but later on can progress to steatohepatitis and cause further liver damage increasing morbidity and mortality [9]. In metabolic disorders, NAFLD is not an innocent bystander. It is an important self-governing risk factor for the cardiovascular disorders (CVD) development [10]. Previous studies reported that, in NAFLD, the secretion of the several atherogenic factors was increased such as cytokines and bad lipoproteins. Hence, fatty liver is considered as an important risk factor for CVD and accounts for increased serum triglycerides, low-density lipoproteins (LDL) and decreased high-density lipoproteins (HDL) [11].

Mediterranean diet is associated with the lower risk of metabolic disorders such as obesity and coronary heart disease [12]. The main ingredient in this diet is olive oil (Olea europaea) which contains oleic acid as a potential fat source with moderate degrees of other fatty acids [13] [14]. Furthermore, it has gained attention by most of the researchers and practitioners as an alternative therapy for some metaflammations rather than recognized as nutritional food only [15]. Olive oil has been commercialized as a food supplement which can be consumed in the form of syrup and capsules. Earlier studies reported the potential therapeutic effects of olive oil such as antioxidant properties, hypotensive, hypoglycemic, cardiovascular, hepatoprotective and anti-asthmatic effects [16]-[21]. Some studies on mammals have shown that, olive oil has positive effects on regulation of cholesterol and oxidation of bad cholesterol (i.e., LDL). Olive oil is rich in monounsaturated fatty acids (MUFA) in the form of oleic acid which accounts for 70\% - 80\% of total fatty acids [22]. Gimeno E. et al., 2010 [23] reported that daily consumption of virgin olive oil about 2 tablespoons for 1 week helps in the lowering of LDL cholesterol oxidation and increases the antioxidant compounds in the blood. It has also been reported that olive oil maintained the plasma lipid pool by regulating the lipid peroxidation and antioxidant parameters [24]. Several studies in vitro suggest that, lipoxygenases, platelet aggregation and eicosanoid production were inhibited by olive oil phenolic compounds [25] [26].

Earlier studies on olive oil showed various beneficial effects on human health, but there was no scientific evidence focusing on the protective effect of olive oil in NAFLD which occurs as a consequence of several metabolic disorders in the present urbanized life styles. The aim of the present study is to access the effect of olive oil (Olea europaea) supplementation against high fat diet induced fatty liver disease in mice.

\section{Materials and Methods}

\subsection{Chemicals}

All the chemicals and reagents used in this experiment were research analytical grade from sigma USA. All assay kits were purchased from Biovision, USA. Extra virgin olive oil was purchased from the local market, Sakaka, Aljouf, K.S.A.

\subsection{Animal Diet}

Basal diet was purchased from Grain Silos \& Flour Mills Organization, Riyadh, Saudi Arabia. It contained the ingredients of $4 \%$ fat; $20 \%$ crude protein; $43.5 \%$ crude fiber; $0.5 \%$ salt, $1 \%$ calcium, $0.6 \%$ phosphorous, $6 \%$ ash, $20 \mathrm{IU} / \mathrm{g}$ vitamin A, $20 \mathrm{IU} / \mathrm{kg}$ vitamin E $20 \mathrm{IU} / \mathrm{g}$ vitamin D, and trace amounts of copper, iron, cobalt, iodine, manganese, zinc and selenium. High-fat diet (HFD) in which $42 \%$ of the energy is derived from fat, was prepared by the addition of 1.5\% cholesterol (Sigma Aldrich, USA) and $8 \%$ coconut oil to the basal diet [27]. The 
HFD was prepared every 2 days and stored at $4^{\circ} \mathrm{C}$.

\subsection{Assay Kits}

Kits for detecting total cholesterol (TC), triglycerides (TG), low density lipoprotein (LDL), high density lipoprotein (HDL), alkaline phosphatase (ALP), alanine aminotransferase (ALT), and alkaline phosphatase (AST) were purchased from Biovision, USA.

\subsection{Acute Toxicity}

The method described by Lorke [28] with slight modification was used to determine the safety of the extra virgin olive oil dose for mice. Briefly, normal healthy mice were divided into groups of five mice in each cage. Olive oil doses of $0.5,1,1.3,1.5$ and $1.7 \mathrm{ml} / \mathrm{kg}$ b.w. were orally administered to animals 10 in number. Free Access to food and water was provided. Toxic symptoms and the general behavior of mice were observed continuously for $1 \mathrm{~h}$ after the treatment, intermittently for $4 \mathrm{~h}$ and thereafter over a period of $24 \mathrm{~h}$. The mice were further observed for up to 14 days following treatment for any signs of toxicity and mortality.

\subsection{Animals and Experimental Design}

Adult Swiss albino mice of either sex (20 - 25 g) were obtained from animal house, College of Medicine, Aljouf University. All protocols were approved by the college ethical committee, Aljouf University. All mice were fed ad libitum with standard laboratory pellet diet and free access to tap water. The experimental mice were maintained under a constant 12 hour light and dark cycle at room temperature. Animals were acclimatized to the new environment for 3 days before the study. After that, the animals were divided into five groups each group 10 in number. Control group (Group I) animals were fed with a normal diet (ND) and High Fat Group (HFD group) was fed with high fat diet (HFD). Group III mice received olive oil (1.3 ml/kg b.w. orally) alone (olive control group/Positive group). Group IV and V received HFD along with olive oil in doses of $1.3 \mathrm{ml} / \mathrm{kg} \mathrm{b.w.} \mathrm{and} 1.7$ $\mathrm{ml} / \mathrm{kg}$ b.w. orally respectively. All mice were fed for 16 weeks. Every two weeks, animal body weights were measured. At the end of the experimental period mice were overnight fasted for 12 hours and it was followed by diethyl ether anesthetization. All the animals were sacrificed by cervical decapitation. Blood samples were collected and stored at $-70^{\circ} \mathrm{C}$ until biochemical analysis. Mice Liver were removed and subjected to histological examination by heamatoxylin and eosin (H\&E) staining.

\section{Biochemical Analysis}

\subsection{Measurements of Lipid Profiles}

Among lipid profiles parameters, concentration of total cholesterol (TC), triglycerides (TG), low density lipoprotein (LDL), high density lipoprotein (HDL) were measured by enzymatic colorimetric methods using commercial assay kits as per manufacture instruction by using Chemwell Semi Biochemistry Analyzer (USA).

\subsection{Biochemical Serum Enzyme Estimations}

Among serum enzyme profile, alkaline phosphatase (ALP), alanine aminotransferase (ALT), and aspartate aminotransferase (AST) were estimated according to the reported methods using assay kits by Chemwell Semi Biochemistry Analyzer (USA).

\subsection{Histological Examination of Liver}

Liver tissues were immediately fixed in $10 \%$ formalin buffer after removal from the animals to avoid decomposition. The tissue samples were embedded in paraffin wax after alcohol dehydration process. By using microtome, $5 \mu \mathrm{m}$ sections of liver tissue were taken and were stained by hematoxylin and eosin stain. All histological slides were analyzed by Leica micro imaging systems DMD 4000, USA.

\subsection{Image Analysis}

The quantification of lipid droplets in the liver sections was measured by the Image J software (NIH, Bethesda, 
MD, USA), which utilizes the color and shape of the images to determine the percentage of lipid droplets in the whole field.

\subsection{Statistical Analysis}

All assay parameters in this study were run in triplicate. Data are expressed as means \pm SD. One-way analysis of variance (ANOVA) was applied by using SPSS, Statistical Package for Social Science (IBM, SPSS Ver. 17.0, SPSS Company, London, UK) for the statistical significance with post-hoc test. $P<0.05$ was considered as statistically significant.

\section{Results}

\subsection{Body Weight Measurement}

Body weight was measured every couple of weeks (Table 1). It was observed that, HFD group animals exhibit a significant increase in body weight as compared to the control group micefed with normal diet $(p<0.05)$. Our results revealed that, Group IV and V mice showed significant $(p<0.05)$ reduction in body weight as compared to HFD group (Table 1). No statistical significance was found between Group IV and V animals as well as control and olive oil control groups mice body weights (Figure 1).

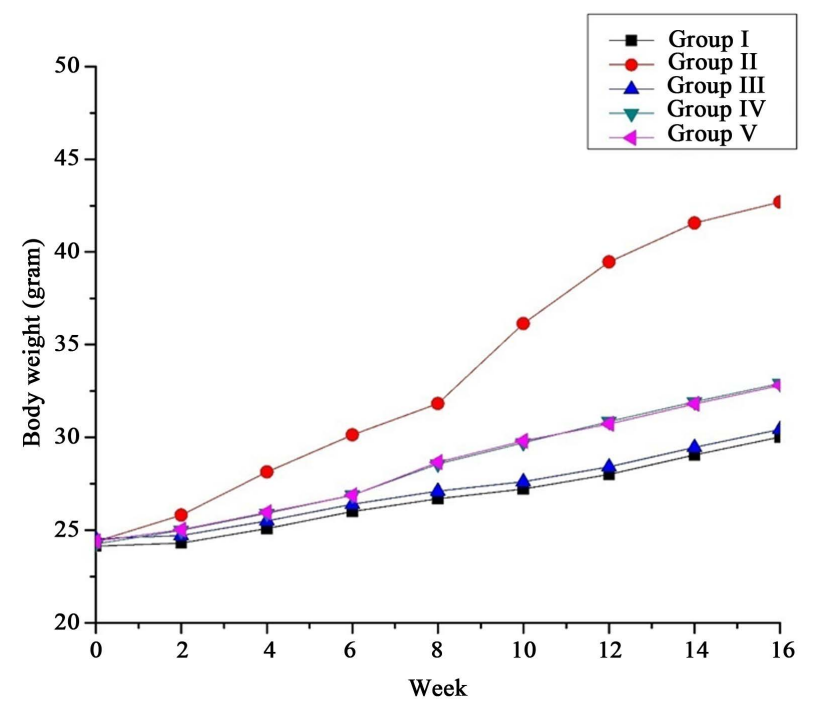

Figure 1. Olive oil potential effect against body weight gain in mice fed with high fat diet.

Table 1. Effect of the different doses of olive oil on body weight gain in mice fed with high fat diet. Data expressed in Mean \pm S.E.

\begin{tabular}{|c|c|c|c|c|c|}
\hline Week & $\begin{array}{c}\text { Group I } \\
(\text { Mean } \pm \text { S.E) }\end{array}$ & $\begin{array}{c}\text { Group II } \\
(\text { Mean } \pm \text { S.E) }\end{array}$ & $\begin{array}{c}\text { Group III } \\
(\text { Mean } \pm \text { S.E) }\end{array}$ & $\begin{array}{c}\text { Group IV } \\
(\text { Mean } \pm \text { S.E) }\end{array}$ & $\begin{array}{c}\text { Group V } \\
(\text { Mean } \pm \text { S.E) }\end{array}$ \\
\hline Week 0 & $24.12 \pm 0.0885$ & $24.37 \pm 0.07$ & $24.53 \pm 0.09$ & $24.24 \pm 0.15$ & $24.4 \pm 0.14$ \\
\hline Week 2 & $24.29 \pm 0.1002$ & $25.81 \pm 0.06$ & $24.70 \pm 0.09$ & $24.98 \pm 0.08$ & $25.01 \pm 0.082$ \\
\hline Week 4 & $25.08 \pm 0.09356$ & $28.12 \pm 0.08$ & $25.49 \pm 0.09$ & $25.90 \pm 0.14$ & $25.95 \pm 0.14$ \\
\hline Week 6 & $25.99 \pm 0.06^{\mathrm{a}, \mathrm{d}}$ & $30.13 \pm 0.11$ & $26.4 \pm 0.05$ & $26.88 \pm 0.10$ & $26.87 \pm 0.10$ \\
\hline Week 8 & $26.69 \pm 0.09^{\mathrm{a}, \mathrm{d}}$ & $31.82 \pm 0.08^{\mathrm{a}}$ & $27.09 \pm 0.08$ & $28.55 \pm 0.20^{\mathrm{a}, \mathrm{b}}$ & $28.65 \pm 0.17^{\mathrm{a}, \mathrm{c}}$ \\
\hline Week 10 & $27.20 \pm 0.07^{\mathrm{a}, \mathrm{d}}$ & $36.12 \pm 0.11^{a}$ & $27.61 \pm 0.07$ & $29.69 \pm 0.09^{\mathrm{a}, \mathrm{b}}$ & $29.79 \pm 0.11^{\mathrm{a}, \mathrm{c}}$ \\
\hline Week 12 & $28.00 \pm 0.07^{\mathrm{a}, \mathrm{d}}$ & $39.46 \pm 0.16^{\mathrm{a}}$ & $28.41 \pm 0.07$ & $30.84 \pm 0.10^{\mathrm{a}, \mathrm{b}}$ & $30.72 \pm 0.12^{\mathrm{a}, \mathrm{c}}$ \\
\hline Week 14 & $29.05 \pm 0.08^{\mathrm{a}, \mathrm{d}}$ & $41.56 \pm 0.09^{\mathrm{a}}$ & $29.46 \pm 0.10$ & $31.91 \pm 0.05^{\mathrm{a}, \mathrm{b}}$ & $31.80 \pm 0.08^{\mathrm{a}, \mathrm{c}}$ \\
\hline Week 16 & $30.01 \pm 0.06^{\mathrm{a}, \mathrm{d}}$ & $42.69 \pm 0.10^{\mathrm{a}}$ & $30.42 \pm 0.07$ & $32.9 \pm 0.15^{\mathrm{a}, \mathrm{b}}$ & $32.8 \pm 0.14^{\mathrm{a}, \mathrm{c}}$ \\
\hline
\end{tabular}

a,b,c,d were statistically significant $(p<0.05)$. No significant variation observed between Group IV and V. 


\subsection{Serum Lipid Parameters}

Olive oil treated groups (Group IV-V) produced significant decrease in the serum triglycerides levels (129.61 \pm 5.50 and $127.93 \pm 8.98 \mathrm{mg} / \mathrm{dl}$ ) as compared to the mice fed with HFD diet group (186.51 $\pm 5.51 \mathrm{mg} / \mathrm{dl}$ ) (Figure 2(a)). Interestingly, group $\mathrm{V}$ mice have more significant decrease in the serum cholesterol level (116.40 \pm 5.71 $\mathrm{mg} / \mathrm{dl})$ than Group IV animals $(121.79 \pm 6.48 \mathrm{mg} / \mathrm{dl})$ as compared to the HFD group $(190.25 \pm 5.13 \mathrm{mg} / \mathrm{dl})$ (Figure 2(b)). The LDL levels were significantly decreased in the Group IV and V mice as compared to HFD group animals (Figure 2(c)) $(p<0.05)$, whereas the levels of HDL were significantly $(p<0.05)$ increased (Figure 2(d)). There was no statistically significant difference observed between control group and olive oil group animals in all lipid parameters (Figures 2(a)-(d)).

\subsection{Serum Enzyme Determination}

The serum levels of AST were significantly increased in HFD Group as compared to other groups $(p>0.05)$ (Figure 3(a)). Group IV \& V mice showed drastically decreased serum ALT levels as compared to HFD group mice (Figure 3(b)). The levels of ALP in Group V \& IV were significantly decreased as compared to HFD group animals (Figure 3(c)). The serum enzyme parameters in olive control group and control groups revealed no statistical difference whereas both groups showed statistically significant difference as compared to HFD group animals (Figures 3(a)-(c)).

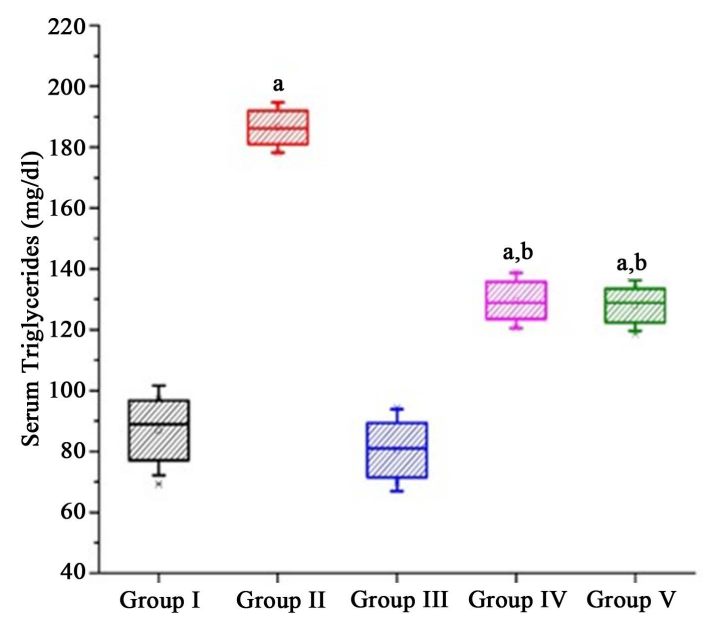

(a)

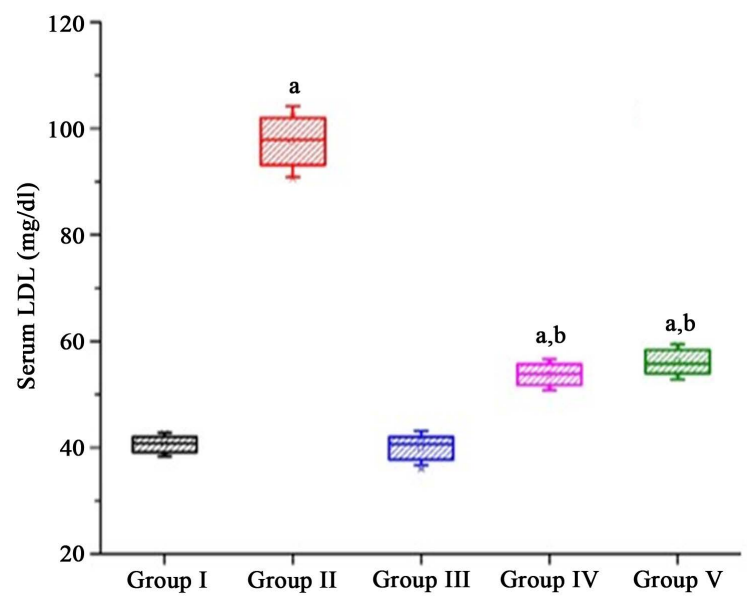

(c)

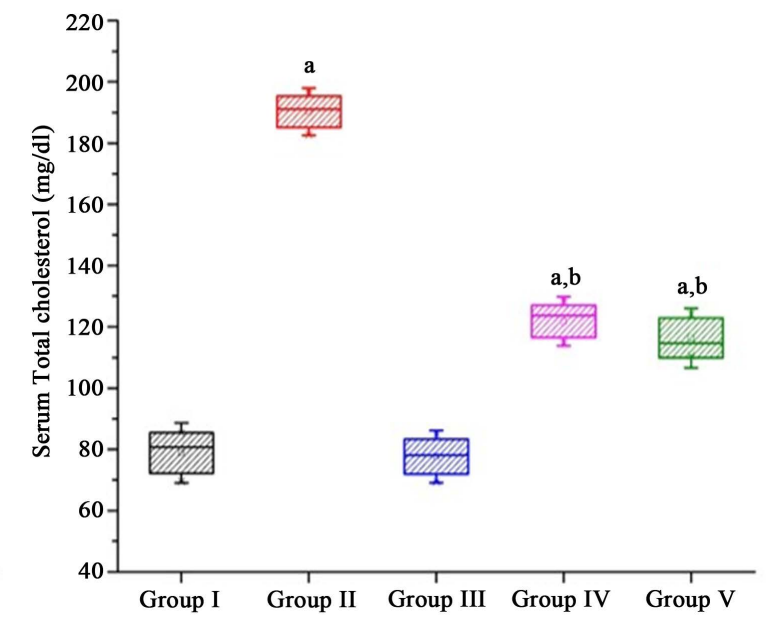

(b)

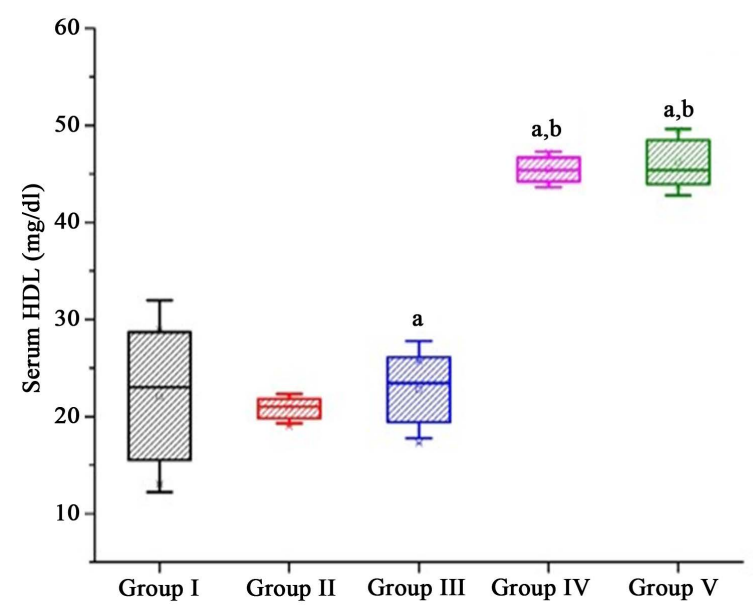

(d)

Figure 2. Effects of olive oil on serum TG (a); TC (b); LDL-C (c) and HDL-C (d) levels in NAFLD mice model. Data were expressed in Mean \pm SD. Error bars with different letters were statistically significant at $p<0.05$. 


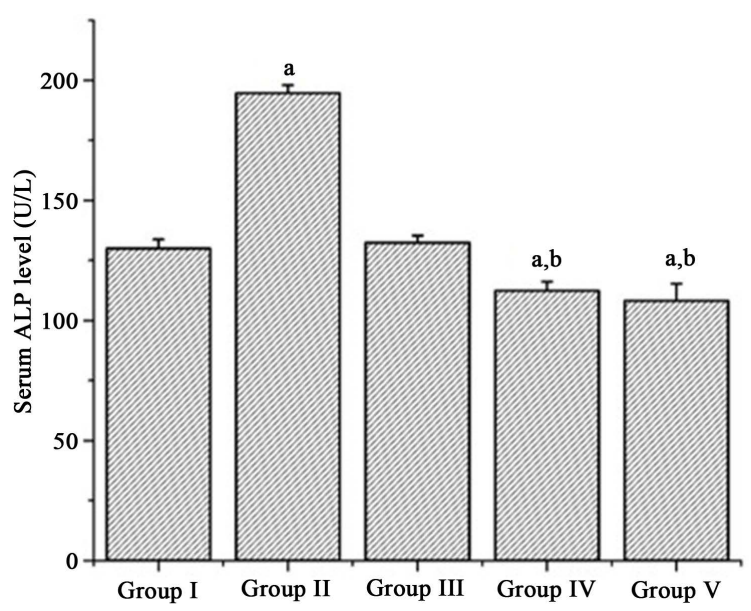

(a)

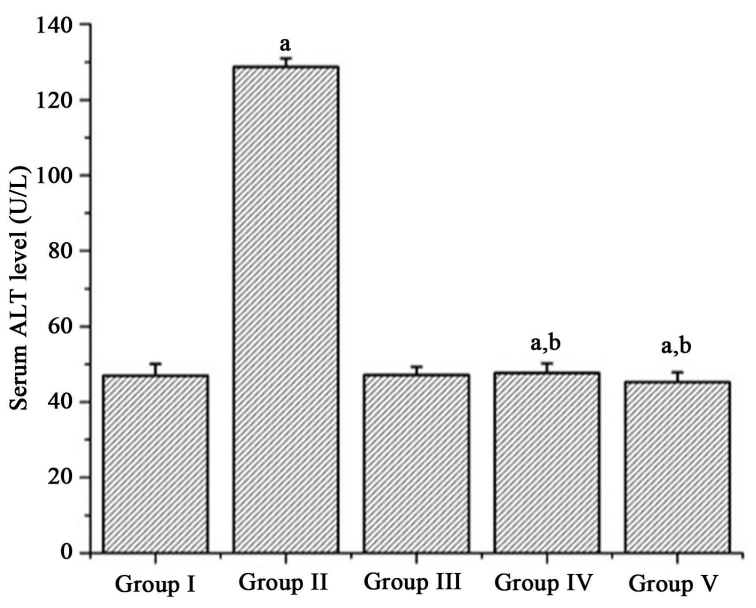

(b)

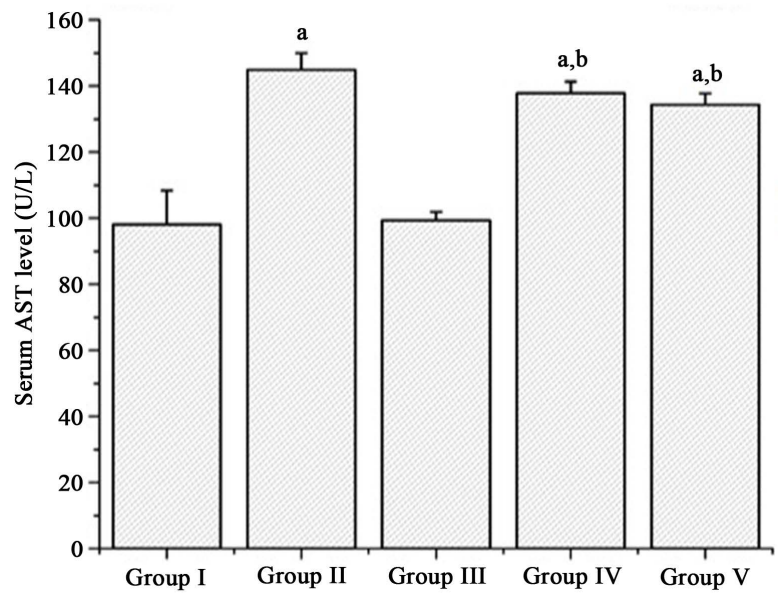

(c)

Figure 3. Effects of olive oil on serum ALP (a); ALT (b); and AST (c) levels in NAFLD mice model. Data were expressed in Mean \pm SD. Error bars with different letters were statistically significant at $p<0.05$.

\subsection{Liver Histology and Quantification}

The liver histology analysis revealed that, the accumulation of lipid droplets was drastically increased in HF group animals as compared to olive oil treated mice (Group IV \& V) (Figures 4(a)-(e)). Results showed that there was no remarkable difference between Group IV and V animals in liver histological sections. Quantification of lipid droplets by Image $\mathrm{J}$ analysis indicated that the percentage of lipid accumulation was significantly increased in HFD Group animals as compared to control group. Alternatively, there was a significant decrease in hepatic lipid droplets in group IV and V animals as compared to High fat diet (HFD) fed animal group.

\section{Discussion}

In developed countries, urbanization and life style modifications lead to the occurrence of Non alcoholic fatty liver disease (NAFLD). NAFLD also occurs as a complication of metabolic syndrome (obesity, hyperglycemia, dyslipidemia, hypertension) [29] which is more common in developed countries. NAFLD accounts for one of the most common causes of chronic liver injury in many developing countries and has gained attention of many researchers as well as medical practitioners as important public health related issue [6] [30]. NAFLD consist of a wide range of disorders which range from simple steatosis to inflammatory steato hepatitis [31] [32]. Currently the most appropriate and clinically validated methods to minimize and control the progression of this disease are acquisition of healthy life styles and proper food habits [33]. Nowadays, different types of therapeutic methods are being used in the treatment of NAFLD and its related disorders. Despite the current therapeutic develop- 


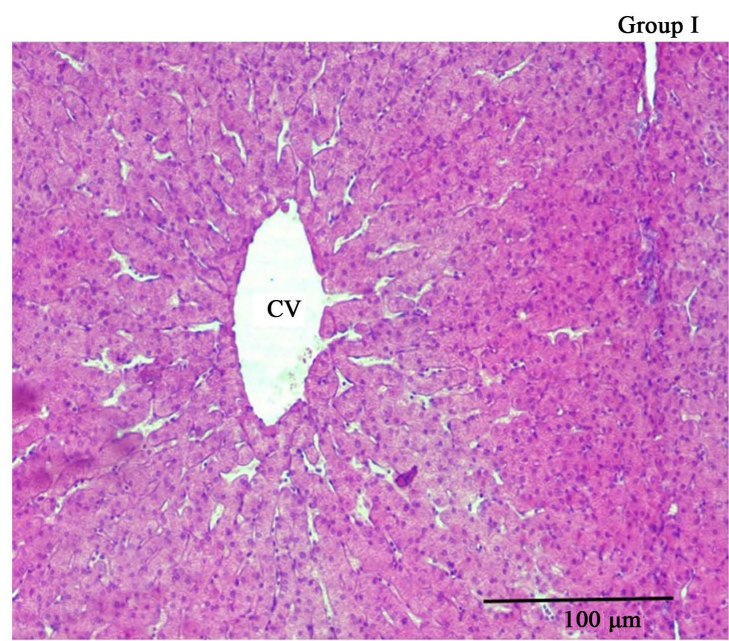

(a)

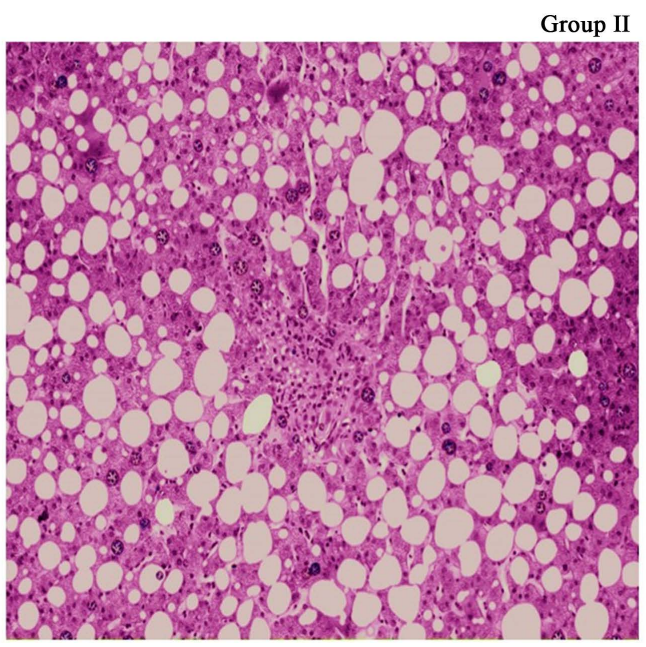

(b)

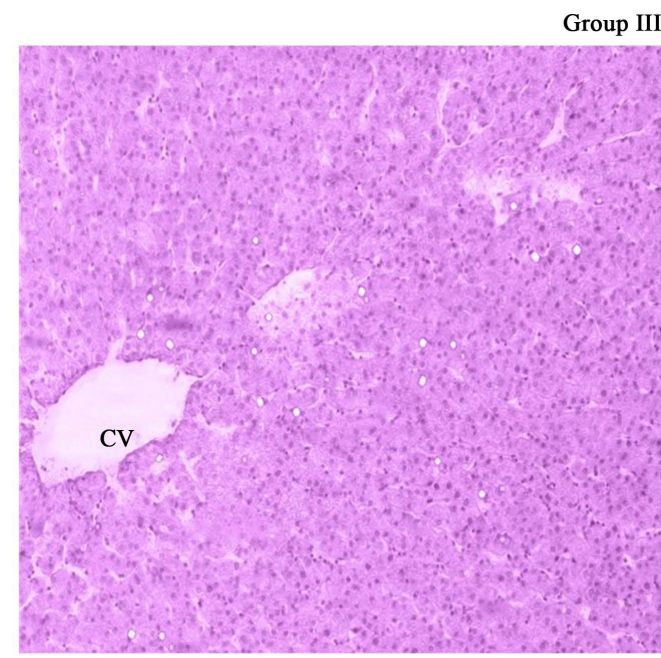

(c)

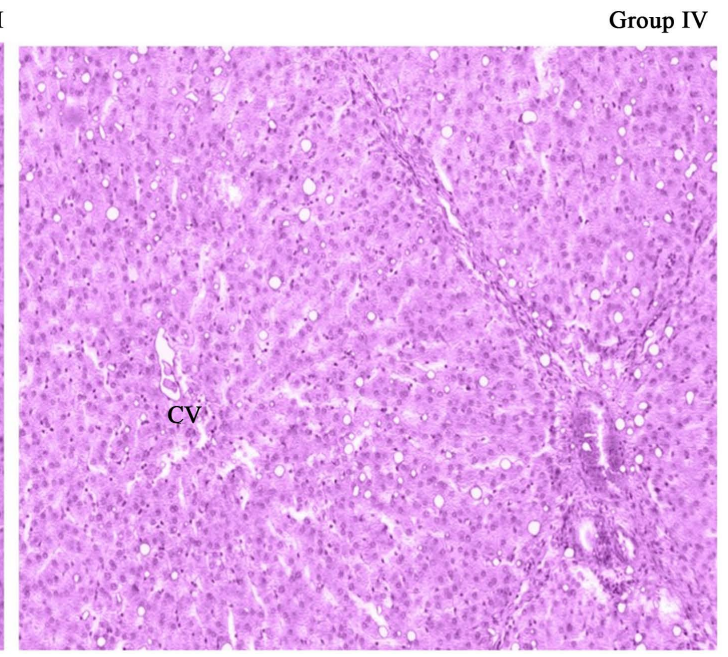

(d)

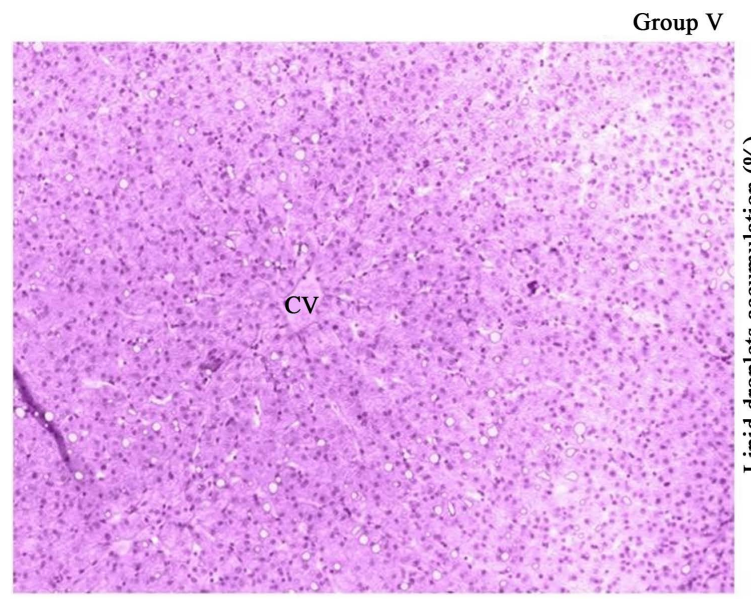

(e)

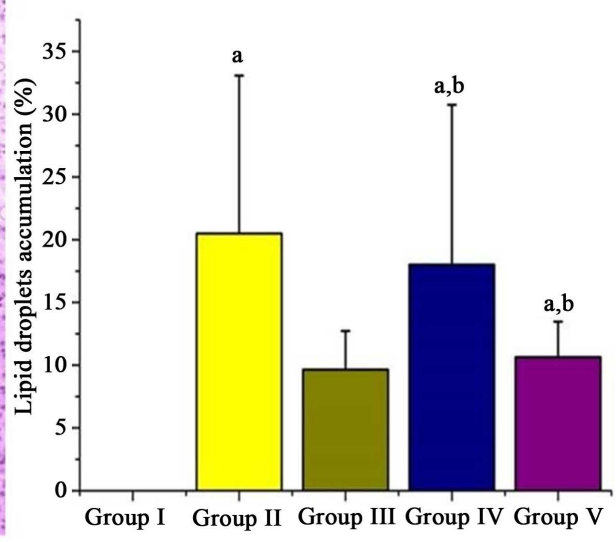

(f)

Figure 4. Effects of olive oil supplementation on hepatic lipid droplet accumulation in HFD-fed mice in NALFD model. Mice were treated as described in (a)-(e) Representative histology of liver sections (100× magnification with the bar indicating $100 \mu \mathrm{m}$ ) stained with hematoxylin/eosin; (f) Quantification of lipid droplet area in the experimental animals. Data are expressed as percentage of the area of lipid droplets in the field. Different letters indicate statistical significance, $p<0.05$. 
ments more attention has been shifted towards plant origin therapy as a possible means of alleviating the NAFLD and its associated symptoms [33] [34], which are easily available, cost effective, convenient and have limited side effects as compared to the synthetic drugs [35] [36]. This study explored the different doses of olive oil ameliorating effect in minimizing the progression of NAFLD in animals fed with high-fat diet for 16 weeks.

Wight loss is a recommended effective treatment of NAFLD [37]. The present study revealed that High-fat diet fed animals treated with olive oil showed significant decrease in the body weights as compared to the highfat diet alone fed animal group (Figure 1). These results are comparable with previous studies which stated that high-fat diet can increase body weight in mice model [37] [38]. In fact the olive oil control group doesn't show any significant weight gain, it is supported by the previous studies that showed that olive oil consumption leads to reduction of weight gain mainly due to MUFA [39].

These results are in agreement with the previous studies in different animal models fed with high-fat diet and olive oil [42]-[44]. Systemic Lipid homeostasis is mainly regulated by liver which manages the redistribution, storage and utilization of triacylglycerol lipoprotein for the peripheral tissues [45]. The level of serum HDL cholesterol showed significant increase in olive treated group animals compared to control and HFD group; in contrast, there is no significant difference between control and HFD group mice. This result contradicted with Manal L. Louka et al., 2012 [46], but conceded with Paoli et al., 2011 [44] results. This controversy may be due to differences in the duration of experimental period.

Serum AST, ALT and ALP are the enzyme biomarkers to monitor the liver structural integrity and damage and aids in the clinical diagnosis of NAFLD and other liver toxicity conditions [47] [48]. Generally high-fat diet increases these enzymes through the induction of oxidative stress in the liver [48]. Our study results showed that HFD group animals had significantly increased levels of AST, ALT, and ALP as compared to control group (Figures 3(a)-(c)), whereas, olive oil treated mice showed significantly $(p<0.05)$ decreased levels of these serum liver enzyme biomarkers as compared to HFD group. This result proved that excessive fat supplementation can show deleterious toxic effect on the liver by the production of free radicals and ROS (reactive oxygen species) [45] [48] which is minimized in Group IV and V mice treated with olive oil. Generally in human population the elevated levels of serum ALT has been suggested as a fatty liver disease [49] and our study results proved that, supplementation of olive oil can decrease the serum ALT levels and protect the liver form toxic effect but it need further scientific trails in human population.

Histological study showed that, HFD group animals has increased number of lipid droplets in the liver section as compared to olive oil treated groups (Figures 4(a)-(e)). This suggested that olive oil may target energy homeostasis mechanism particularly in the liver and reduced the hepatic lipid droplet accumulation. The results from the liver section quantification revealed that the accumulation of fat percentage was increased in HFD group mice indicating severe steatosis in the liver cells as compared to olive oil treated animals (Figure 4(f)). Current biochemical analysis results are also in agreement with the histological study which shows that olive oil supplementation can minimize the liver toxicity and control the progression of NAFLD. This result is in agreement with the study done by Al-Rawi M. and Ali A. which showed the hepatoprotective activity of olive oil in rat fed with high-fat diet [50].

\section{Conclusion}

Supplementation of olive oil decreases the serum triglycerides, normalizes the liver enzyme biomarkers and significantly reduces the fat droplet accumulation in liver by suppressing the inflammation and restoring the abnormal lipid metabolisms in experimental animals. NAFLD is mainly controlled by reducing the weight gain and the study results showed that olive oil causes weight reduction hence it is indirectly related to control the NAFLD but the underlying mechanisms remain to be identified. Thus, it is suggested that olive oil may represent a potential ameliorating therapeutic alternative for targeting NAFLD and other fatty diseases associated with chronic health problems resulting from modern life styles and eating habits. However, further studies are still required to find out the exact mechanism behind potential effect.

\section{Financial Support}

Project funded by Aljouf University. 


\section{Acknowledgements}

This work was funded by the research grants from the Aljouf University. The team is extremely thankful to the Pathology department for facilitating the working of the project.

\section{Author's Contribution}

Dr. Farooq Ahmed Wani: Study concept and design; acquisition, analysis and interpretation of data; drafting and critical revision of the manuscript, final approval and agreement regarding the manuscript. Obtained funding and provided administrative, technical and material support.

Abdalla Z. Albahrawy: Study concept and design; acquisition, analysis and interpretation of data; drafting and critical revision of the manuscript, final approval and agreement regarding the manuscript.

ShaikRahiman: Study concept and design; acquisition, analysis and interpretation of data; drafting and critical revision of the manuscript, final approval and agreement regarding the manuscript. Major contribution in statistical analysis.

\section{References}

[1] Hamelet, J., Demuth, K., Paul, J.L., Delabar, J.M. and Janel, N. (2007) Hyperhomocysteinemia due to Cystathionine Beta Synthase Deficiency Induces Dysregulation of Genes Involved in Hepatic Lipid Homeostasis in Mice. Journal of Hepatology, 46, 151-159. http://dx.doi.org/10.1016/j.jhep.2006.07.028

[2] Shahani, A. and Handa, S.S. (1995) Hepatoprotective Activity of Apium graveolens and Hygrophill aauriculata against Paracetamol and Thioacetamide Intoxicationin in Rats. Journal of Ethnopharmacology, 49, 119-126. http://dx.doi.org/10.1016/0378-8741(95)01291-5

[3] Adams, L.A. and Angulo, P. (2005) Recent Concepts in Non-Alcoholic Fatty Liver Disease. Diabetic Medicine, 22, 1129-1133. http://dx.doi.org/10.1111/j.1464-5491.2005.01748.x

[4] SuriyavathanaVedanarayanan, M. and Krishnan, N. (2011) Ayurvedic Formulation of Liv-Pro-08 Reduces Nonalcoholic Fatty Liver Disease in Rats Fed with High-fat Diet. Journal of Acupuncture and Meridian Studies, 4, 236-241. http://dx.doi.org/10.1016/j.jams.2011.09.014

[5] Angulo, P. (2002) Nonalcoholic Fatty Liver Disease. The New England Journal of Medicine, 346, 1221-1231. http://dx.doi.org/10.1056/NEJMra011775

[6] Clark, J.M. (2002) Nonalcoholic Fatty Liver Disease. Gastroenterology, 122, 1649-1657. http://dx.doi.org/10.1053/gast.2002.33573

[7] Grattagliano, I., Palmieri, V.O., Portincasa, P., Moschetta, A. and Palasciano, G. (2008) Oxidative Stress-Induced Risk Factors Associated with the Metabolic Syndrome: A Unifying Hypothesis. The Journal of Nutritional Biochemistry, 19, 491-504. http://dx.doi.org/10.1016/j.jnutbio.2007.06.011

[8] Videla, L.A., Rodrigo, R., Araya, J. and Ponichik, J. (2006) Insulin Resistance and Oxidative Stress Interdependency in Non-Alcoholic Fatty Liver Disease. Trends in Molecular Medicine, 12, 555-558. http://dx.doi.org/10.1016/j.molmed.2006.10.001

[9] Adams, L.A., Lymp, J.F., St. Sauver, J., et al. (2005) The Natural History of Non-Alcoholic Fatty Liver Disease: A Population-Based Cohort Study. Gastroenterology, 129, 113-121. http://dx.doi.org/10.1053/j.gastro.2005.04.014

[10] Fon Tacer, K. and Rozman, D. (2011) Nonalcoholic Fatty Liver Disease: Focus on Lipoprotein and Lipid Deregulation. Journal of Lipids, 2011, 1-14. http://dx.doi.org/10.1155/2011/783976

[11] Musunuru, K. (2010) Atherogenic Dyslipidemia: Cardiovascular Risk and Dietary Intervention. Lipids, 45, 907-914. http://dx.doi.org/10.1007/s11745-010-3408-1

[12] Knoops, K.T.B., de Groot, L.C.P., Kromhout, D., Perrin, A.E., Moreiras-Varela, O., Menotti, A., et al. (2004) Mediterranean Diet, Lifestyle Factors, and 10-Year Mortality in Elderly European Men and Women. JAMA, 292, 1433-1446. http://dx.doi.org/10.1001/jama.292.12.1433

[13] Lou-Bonafonte, J., Arnal, C., Navarro, M. and Osada, J. (2012) Efficacy of Bioactive Compounds from Extra Virgin Olive Oil to Modulate Atherosclerosis Development. Molecular Nutrition \& Food Research, 56, 1043-1057. http://dx.doi.org/10.1002/mnfr.201100668

[14] Kok, F.J. and Kromhout, D. (2012) Atherosclerosis-Epidemiological Studies on the Health Effects of a Mediterranean diet. European Journal of Nutrition, 43, I/2-I/5.

[15] Stark, A.H. and Madar, Z. (2002) Olive Oil as a Functional Food: Epidemiology and Nutritional Approaches. Nutrition Reviews, 60, 170-176. http://dx.doi.org/10.1301/002966402320243250 
[16] Benavente-Garcia, O., Castillo, J., Lorente, J. and Alcaraz, M. (2002) Radioprotective Effects in Vivo of Phenolics Extracted from Olea europaea L. Leaves against X-Ray Induced Chromosomal Damage: Comparative Study versus Several Flavonoids and Sulfur-Containing Compounds. Journal of Medicinal Food, 5, 125-135. http://dx.doi.org/10.1089/10966200260398152

[17] Khayyal, M.T., El-Ghazaly, M.A., Abdallah, D.M., Nassar, N.N., Okpanyi, S.N. and Kreuter, M.H. (2002) Blood Pressure Lowering Effect of an Olive Leaf Extract (Olea europaea) in L-NAME Induced Hypertension in Rates. Arzneimittel-Forschung, 52, 797-802.

[18] Komaki, F., Yamaguchi, E., Maru, S., Kinoshita, M., Kakehi, K., Ohta, Y., et al. (2003) Identification of Anti-Alpha-Amylase Components from Olive Leaf Extracts. Food Science and Technology Research, 9, 35-39. http://dx.doi.org/10.3136/fstr.9.35

[19] Bouaziz, M. and Sayadi, S. (2005) Isolation and Evaluation of Antioxidants from Leaves of a Tunisian Cultivar Olive Tree. European Journal of Lipid Science and Technology, 107, 497-504. http://dx.doi.org/10.1002/ejlt.200501166

[20] Poudyal, H., Campbell, F. and Brown, L. (2010) Olive Leaf Extract Attenuates Cardiac, Hepatic and Metabolic Changes in High Carbohydrate-, High Fat-Fed Rats. The Journal of Nutrition, 140, 946-953. http://dx.doi.org/10.3945/jn.109.117812

[21] Wani, F.A., Rahiman, S. and Tantry, B.A. (2015) Evaluation of Anti Asthmatic Effect of Extra Virgin Olive Oil (Olea europea) Against Milk Induced Leukocytosis and Eosinophilia. Advances in Bioresearch, 6, 15-18.

[22] López-Miranda, J., Pérez-Jiménez, F., Ros, E., De Caterina, R., Badimón, L., Covas, M.I., et al. (2010) Olive Oil and Health: Summary of the II International Conference on Olive Oil and Health Consensus Report, Jaen and Cordoba (Spain) 2008. Nutrition, Metabolism and Cardiovascular Diseases, 20, 284-294. http://dx.doi.org/10.1016/j.numecd.2009.12.007

[23] Gimeno, E., Fitó, M., Lamuela-Raventós, R.M., Castellote, A.I., Covas, M., Farré, M., et al. (2002) Effect of Ingestion of Virgin Olive Oil on Human Low-Density Lipoprotein Composition. European Journal of Clinical Nutrition, 56, 114-120. http://dx.doi.org/10.1038/sj.ejcn.1601293

[24] Gorinstein, S., Leontowicz, H., Lojek, A., Leontowicz, M., Ciz, M., Krzeminski, R., et al. (2002) Olive Oils Improve Lipid Metabolism and Increase Antioxidant Potential in Rats Fed Diets Containing Cholesterol. Journal of Agricultural and Food Chemistry, 50, 6102-6108. http://dx.doi.org/10.1021/jf020306k

[25] de la Puerta, R., Ruiz Gutierrez, V. and Hoult, J.R. (1999) Inhibition of Leukocyte 5-Lipoxygenase by Phenolics from Virgin Olive Oil. Biochemical Pharmacology, 57, 445-449. http://dx.doi.org/10.1016/S0006-2952(98)00320-7

[26] Petroni, A., Blasevich, M., Salami, M., Papini, N., Montedoro, G.F. and Galli, C. (1995) Inhibition of Platelet Aggregation and Eicosanoid Production by Phenolic Components of Olive Oil. Thrombosis Research, 78, 151-160. http://dx.doi.org/10.1016/0049-3848(95)00043-7

[27] Mukundh, N.B., Muralidharan, P. and Balamurugan, G. (2008) Anti Hyperlipidemic Activity of Pedalium murex (Linn.) Fruits on High Fat Diet Fed Rats. International Journal of Pharmacology, 4, 310-313. http://dx.doi.org/10.3923/ijp.2008.310.313

[28] Lorke, D. (1983) A New Approach to Practical Acute Toxicity Testing. Archives of Toxicology, 53, 275-289. http://dx.doi.org/10.1007/BF01234480

[29] Hamaguchi, M., Kojima, T., Takeda, N., Nakagawa, T., Taniguchi, H., Fujii, K., et al. (2005) The Metabolic Syndrome as a Predictor of Nonalcoholic Fatty Liver Disease. Annals of Internal Medicine, 143, 722-728. http://dx.doi.org/10.7326/0003-4819-143-10-200511150-00009

[30] Elahi, R.K. (2012) Preventive Effects of Turmeric (Curcuma longa Linn.) Powder on Hepatic Steatosis in the Rats Fed with High Fat Diet. Life Science Journal, 9, 5462-5468.

[31] Pascos, P. and Paletas, N. (2009) Nonalcoholic Fatty Liver Disease and Metabolic Syndrome. Hippokrata, 1, 9-19.

[32] Asari, J.A., Sayyed, M. and Sayyed, F. (2011) Management of Non-Alcoholic Fatty Liver Disease and Their Complications. International Journal of Pharmaceutics, 5, 579-588.

[33] Xiao, J., Guo, R., Fung, M.L., Liong, E.C. and Tipoe, G.L. (2013) Therapeutic Approaches to Non-Alcoholic Fatty Liver Disease: Past Achievements and Future Challenges. Hepatobiliary \& Pancreatic Diseases International, 12, 125-135. http://dx.doi.org/10.1016/S1499-3872(13)60021-1

[34] Tan, Y., Lao, W., Xiao, L., Wang, Z., Xiao, W., Kamal, M.A., et al. (2013) Managing the Combination of Nonalcoholic Fatty Liver Disease and Metabolic Syndrome with Chinese Herbal Extracts in High-Fat-Diet Fed Rats. Evidence-Based Complementary and Alternative Medicine, 2013, Article ID: 306738.

[35] Thoma, C., Day, P. and Trenell, M.I. (2012) Lifestyle Interventions for the Treatment of Non-Alcoholic Fatty Liver Disease in Adults: Asystematic Review. Journal of Hepatology, 56, 255-266. http://dx.doi.org/10.1016/j.jhep.2011.06.010

[36] Adams, L.A. and Angulo, P. (2006) Treatment of Non-Alcoholic Fatty Liver Disease. Postgraduate Medical Journal, 82, 315-322. http://dx.doi.org/10.1136/pgmj.2005.042200 
[37] Han, L.K., Kimura, Y. and Okuda, H. (1999) Reduction in Fat Storage during Chitin-Chitosan Treatment in Mice Fed a High Fat Diet. International Journal of Obesity, 23, 174-179. http://dx.doi.org/10.1038/sj.ijo.0800806

[38] Han, L.K., Sumiyoshi, M., Takida, T., Chihara, H., Nishikiori, T., Tsujita, T., et al. (2000) Inhibitory Effects of Chondroitin Sulfate Prepared from Salmon Nasal Cartilage on Fat Storage on Mice Fed a High Fat Diet. International Journal of Obesity, 24, 1131-1138. http://dx.doi.org/10.1038/sj.ijo.0801378

[39] Bes-Rastrollo, M., Sánchez-Villegas, A., de la Fuente, C., de Irala, J., Martínez, J.A. and Martínez-González, M.A. (2006) Olive Oil Consumption and Weight Change: The SUN Prospective Cohort Study. Lipids, 41, 249-256. http://dx.doi.org/10.1007/s11745-006-5094-6

[40] Pérez-Martínez, P., García-Ríos, A., Delgado-Lista, J., Pérez-Jiménez, F. and López-Miranda, J. (2011) Mediterranean Diet Rich in Olive Oil and Obesity, Metabolic Syndrome and Diabetes Mellitus. Current Pharmaceutical Design, 17, 769-777. http://dx.doi.org/10.2174/138161211795428948

[41] Keys, A., Menotti, A., Karvonen, M.J., Aravanis, C., Blackburn, H., Buzina, R., et al. (1986) The Diet and 15-Year Death Rate in the Seven Countries Study. American Journal of Epidemiology, 124, 903-915.

[42] Jones, P.J.H., Demonty, I., Chan, Y.M., Herzog, Y. and Pelled, D. (2007) Fish-Oil Esters of Plant Sterols Differ from Vegetable-Oil Sterol Esters in Triglycerides Lowering, Carotenoid Bioavailability and Impact on Plasminogen Activator Inhibitor-1(PAI-1) Concentrations in Hypercholesterolemic Subjects. Lipids in Health and Disease, 6, 28-37. http://dx.doi.org/10.1186/1476-511X-6-28

[43] Alhazza, I.M. (2007) Antioxidant and Hypolipidemic Effects of Olive Oil in Normal and Diabetic Male Rats. Saudi Journal of Biological Sciences, 14, 69-74.

[44] Paoli, A., Cenci, L. and Grimaldi, K.A. (2011) Effect of Ketogenic Mediterranean Diet with Phyto Extracts and Low Carbohydrates/High Protein Meals on Weight, Cardiovascular Risk Factors, Body Composition and Diet Compliance in Italian Council Employees. Nutrition Journal, 10, 112-120. http://dx.doi.org/10.1186/1475-2891-10-112

[45] Donnelly, K.L., Smith, C.I., Schwarzenbirg, S.L., Jessurun, J., Boldt, M.D. and Parks, E.J. (2005) Sources of Fatty Acids Stored in Liver and Secreted via Lipoproteins in Patients with Non-Alcoholic Fatty Liver Disease. Journal of Clinical Investigation, 115, 1343-1351.

[46] Louka, M.L., Habib, H.Z., Youssef, M.H.M. and Nassef, N.A.H. (2012) Effect of Olive Oil Supplementation on PAI-1 Expression in Old Rats. The Journal of American Science, 8, 317-321.

[47] Simon-Giavaritti, K.A., Giavarotti, L., Gomes, L.F., Lima, A.F., Veridin, A.M., Garcia, E.A., et al. (2002) Enhancement of Lindane-Induced Liver Oxidative Stress and Hepatotoxicity by Thyroid Hormone Is Reduced by Gadolinum Chloride. Free Radical Research, 36, 1033-1039. http://dx.doi.org/10.1080/1071576021000028280

[48] Amin, A. and Hamza, A.A. (2005) Oxidative Stress Mediates Drug-Induced Hepatotoxicity in Rats a Possible Role of DNA Fragmentation. Toxicology, 208, 367-375. http://dx.doi.org/10.1016/j.tox.2004.11.039

[49] Falck-Ytter, Y., Younossi, Z.M., Marchesini, G. and McCullough, A.J. (2001) Clinical Features and Natural History of Nonalcoholic Steatosis Syndromes. Seminars in Liver Disease, 21, 17-26. http://dx.doi.org/10.1055/s-2001-12926

[50] Al-Rawi, M. and Ali, A. (2010) Efficacy of Olive Oil Diet on the Histopathological Changes Induced in Hypercholesterolemic Rat. Egyptian Academic Journal of Biological Sciences, 2, 1-9.

\footnotetext{
Abbreviations Used

NAFLD = Non alcoholic fatty liver disease;

NASH = Non alcoholic steatohepatitis;

CVD = Cardiovascular disease;

LDL = Low density lipoprotein;

HDL = High density lipoprotein;

HFD = High Fat Diet;

$\mathrm{TC}=$ Total cholesterol;

TG = Triglycerides;

ALP = Alkaline phosphatase;

ALT = Alanine transaminase;

AST $=$ Aspartate transaminase;

$\mathrm{ND}=$ Normal diet;

MUFA = Monounsaturated fatty acids.
} 